\title{
Institutional Collaboration as Essential Ingredient for Efficient and Effective Service Delivery: A Critical Focus on the Tripodic Super-bureaucracies and Bureaucrats in Ekiti State, Nigeria
}

\author{
Sunday Tunde Akindele ${ }^{1}$, Oluwadare Ojo Ayeni ${ }^{2} \&$ Yakibi Ayodele Afolabi ${ }^{3}$ \\ ${ }^{1}$ Department of Political Science, Obafemi Awolowo University, Ile-Ife, Nigeria \\ ${ }^{2}$ Department of Public Administration, Obafemi Awolowo University, Ile-Ife, Nigeria \\ ${ }^{3}$ Department of Business Administration and Management, Osun State Polytechnic, Iree, Nigeria \\ Correspondence: Sunday Tunde Akindele, Department of Political Science, Obafemi Awolowo University, \\ Ile-Ife, Nigeria. Tel: 234-803-711-6276. E-mail: sxakindel@yahoo.com
}

Received: February 25, 2012 Accepted: March 9, 2012 Online Published: November 29, 2012

doi:10.5539/jpl.v5n4p111 URL: http://dx.doi.org/10.5539/jpl.v5n4p111

\begin{abstract}
This paper, using Ekiti State, Nigeria as a case study examines the issue of collaboration and its nexus with effective and efficient responsive service delivery to the citizenry. It takes off with a discussion of the relevant concepts that give both theoretical and practical expressions to the Offices of the SSG; HOS and; CSC vis-à-vis their coordinate relational partnerships. In the process, the deep-seated history; functions as well as the problems and challenges of these offices were concretely highlighted. While the benefits of collaboration among them were identified and critically examined, the need for the super-bureaucracies and bureaucrats in the state to create conducive atmospheres for the continuous sustenance of collaboration was stressed as the only avenue for the civil service to regain its lost glory and attain relevance in today's global village in line with the ethos of public administration of the $21^{\text {st }}$ century.
\end{abstract}

Keywords: tripodic super-bureaucracy, institutionalism, collaboration, public service, administrative cadre, democracy, governance, accountability, change leadership, transformation strategy, service delivery, professionalism

\section{Introduction}

This paper deals with the issue of institutional collaboration as ingredient for efficient and effective service delivery to the citizenry. It critically focuses on the tripodic super- bureaucracies - [Offices of the SSG, HOS and, CSC] - and their Practitioners in Ekiti State. It attempts how the avoidable inter and intra institutional agencies of government's wrangling, buck-passing on important policy issues, legislative conflicts, paucity of constitutional provisions and their interpretations which had hitherto caused problems in the absence of collaboration can be recognized and rectified through cooperative inter relationship.

\section{Conceptual Analysis}

The paper commences with the discussion of the concepts of institutionalism and public service as constructs that give theoretical and practical expressions to the offices under reference. This is followed by the discussions of institutional collaboration; its enhancers or facilitators and; why the super-bureaucracies and bureaucrats must collaborate; benefits and conditions associated with collaboration and; the conclusion.

\subsection{Institutionalism}

This is the belief that underlies the nature of institution. It is a "belief in the usefulness or sanctity of established institution" (Webster Dictionary) hence, institutions have been described as "the beliefs, paradigms, codes, cultures, and knowledge that support rules and routines" (March and Olson, 1984). It is a concept that "sees organizations as social construct of rules, roles, norms, and the expectations that constrain individual and group choice and behavior" (Frederickson, 1999).

According to Powell and DiMaggio (1991), institutionalism includes core ideas of contemporary public administration - [results, performance, outcomes, and purposefulness] - concepts. Thus, institutionalism as a concept "could be said to account for both how institutions behave and how they perform" (Lynn, 1996). 
institutionalism also combines the structural or organizational elements of institutions and the managerial and leadership elements of institutions (Rainey and Steinbauer 1999; Frederickson, 1999; Wilson 1989) hence, as Kettl (1988; 1993); Light (1999) and; Salomon (1989) posited “institutionalism is not limited to formal governmental organizations as it now includes empirical and theoretical considerations of the full range of the so-called "third sector" organization" [e.g. the informal organizations, groups and interests].

Given these, it is clear that some of the theorists on the concept while giving relevance to "the limitations of economics and market logic as the theory that accounts for institutional behavior", have built their theories on the subject on:

Consideration of structure, particularly hierarchy, and individual and group behavior in institutional contexts, on the interaction of individuals and organizations and their wider political, social, and economic contexts, and on the influence of professional and cultural norms on institutional behavior patterns and on institutional longevity and productivity (Wilson, Ibid.; March and Olsen Ibid).

It is generally accepted within the boundaries of public administration in the twenty-first century that all Public Administrators are "institutionalists" to the extent that the "new public administration hegemony" in this century has emerged based "on a broadly accepted institutionalism" (Frederickson, Op.cit). In the process it has been clearly articulated that:

Institutionalism is not a theory in the formal sense, but is, instead, the framework, the language, and the set of assumptions that hold and guide empirical research and theory building in public administration. It begins with an argument as to the salience of collective organizational action as a basis for understanding political and social institutions...Institutions are affected by their social, economic, and political context but also powerfully affect that context (Ibid.; Schattneider, 1960).

This explains the critical contention that "political democracy depends not only on economic and social contributions but also on the design of political institutions" (March and Olsen, Ibid.).

\subsection{Public Service}

Impartial students of political science and, indeed public administration, will agree with a synopsis which asserts that Public service has constantly played a significant role in shaping the making and implementation of government policies and programs. Thus, the term public service refers to all public employees, while civil service is limited to government employees who are appointed on the basis of examination given by the civil service commission and who acquire civil service status after a probationary period.

The seeming dichotomy or differences between the two notwithstanding, public service or civil service as the case may be belongs to the landscape of the public sector of any given political system. Although, the public service today, is an indispensable organ of government, especially with the emergence of modern states and consequent complexities in government activities, it history is deep-seated (Ibodje, 2000).

In Nigeria, the present status of civil service is a product of various changes it had undergone. These changes are not only as a result of the need to strengthen its capacity for efficient and effective performance of the governmental functions but because of the seeming need to respond to the dynamic nature of the country's political, social and economic developments.

There is no doubt about the fact that the structure and nature of the country's civil service before independence was patterned along the British model. This notwithstanding however, the decade or so before independence could be regarded as transitional with the introduction of some various administrative and social changes, including the elements of Nigerianisation of the civil service among other things.

\section{The Issue of Institutional Collaboration}

Collaboration - which means cooperation and harmonious working together for the attainment of set goals among the institutions of the state is without doubt important to the attainment of the end result - good governance, efficient and effective (responsive) service delivery to the citizenry - of the existential wherewithal of the state. Even though, the compelling forces for collaboration among these administrative arms - Ministries, Departments and Agencies-MDAs - of government are wide, the real factors can be understood within the boundaries of the rigid character of Nigeria's federalism and its intergovernmental relations. 


\subsection{Collaboration among the Three Super-bureaucracies of the State}

In order for Nigeria and Nigerians to attain the benefits inherent in the provision of "effective public service delivery" and, creation of workable road map to economic development, there must be unity of purpose among the tripodic super-Bureaucracies - [Offices of the SSG; HOS and CSC] - particularly in the areas of policy initiation, formulation, implementation, interpretation and evaluation in the quest for responsive governance.

Collaboration among these administrative arms and their practitioners in Ekiti state can be attained through various means. However such attainment is contingent on certain things that must or should be done in the quest for administrative efficiency and effectiveness vis-à-vis meeting the needs and aspirations of the citizenry.

The first thing to be done in this regard is to truly understand and embrace the need for collaboration as well as where the relevant actors both at the governmental/political and citizenry levels stand in the scheme of things within the landscape of the political system. This is more so because, the indispensability of the criteria of "good governance", "good economics", "sane budgetary process", "participatory budgeting", "professionalism of the public bureaucracies and the practitioners within them", "cordiality of political actors and actions among the three organs of government", to the attainment and sustenance of "effective public service delivery" and "politics of hope" for the Nigerian people compels the need for collaboration. This collaboration among various administrative and governmental units is in line with the imperatives of today's existential globalism which clearly constrains unproductive and arrogant independence, individualism or isolationism in preference for collaborative efforts. And, it can only be taken for granted at any nation's perils.

In order for the Public Bureaucracies and the Practitioners within them to be relevant and provide the requisite guidance and technocratic road map for the political actors in the quest for effective public service delivery, there must be collaboration among them vis-à-vis the issue of public policy and its processes within the state. Collaboration is needed among these administrative organs in order to ensure responsive, efficient and effective governance; collectively inculcate the values of accountability and, reduce to the barest minimum or completely avoid administrative corruption which has consistently wrecked the engine of good governance and true democracy in Nigeria. Such avoidance of corruption is critically important because, corruption is a threat to democratic culture and it "remains the most invidious obstacle to stability in Nigeria both under the military and civilians. It is a socio-political, economic and moral malaise that may permeate and cripple, as a result of its contagiousness and malignancy, the nerves of any polity. It is "an intolerable characteristic" that should be discouraged in governance because once it sets into any part; it automatically contaminates all the strata of that system's hierarchy in ways symmetrical to the spread of a bush fire (Kukah, 1995; Fullerton, 2002; Akindele and Adeyemi, 2011). And, the only antidote to its unrelenting effects is accountability. Thus, the internalization of the values of accountability and its propeller - [transparency] - by our Public Administrators is a sine-qua-non to administrative efficiency and efficacy vis-à-vis the pursuit of good governance and responsive service delivery.

Accountability connotes a way of being answerable or liable for one's actions and/or inactions and, conduct in office or position. It is the process of making elected officials and other office holders accountable and responsible to the people who elected or appointed them for their actions while in the office. Thus, it is the "state or quality of being liable and required by a specified person or group of people to report and justify the actions of people in office in relations to specific matters or assigned duties. Accountability requires faithful discharge of one's duty in ways that fulfils the public interest or the interests of those who entrust such responsibility to the office holder(s). According to Gould and Kolb (1964); Gould, (1972), accountability "focuses attention upon the sanctions or procedures by which public officials may be held to account for their actions (and /or inactions) (Emphasis mine) (see Erero, 2000: 52 and Adamolekun 1983:17). Within this same context, it has been conceived as a process through which "the administrative state has to render an account of its performance to its sovereign, the people" (Wolfgang, 1991:7 and Erero, Ibid.).

Put together, accountability is "the obligation of public office holders to take responsibility for their actions. It exists when power-holders have to explain and justify their actions or face sanctions" (Malena and McNeil, 2010). Thus, it is "the cornerstone of good governance and, unless public officials can be held to account, critical benefits associated with good governance-such as social justice, poverty reduction, and development will remain elusive"(Akindele and Adeyemi, 2011). With accountability comes transparency which, on its own means openness. It is a component of ethical values expected to be demonstrated by the people in official positions vis-à-vis government activities on issues of public accounts, budgets, politics, programmes, legislations and, contract awards amongst others. It allows the government to carry along the citizens and allow the latter to participate and contribute to day-to-day running and administration of Government. 


\section{Professionalism of the Practitioners within the Public Service as a Facilitator of Collaboration}

The collaboration under reference will be more attainable if our public service and its functionaries are accountable and professional in the conduct and performance of their functions vis-à-vis the raison d'être of the state.

\subsection{Professionalism in the Civil Service: The Particularistic Perspective}

There is a need for professionalism in the civil service. However, such professionalism is particularistic and individualistic rather than institutional or systemic. The particularistic professionalism of the careerists will add more values and vitality to the service better than the institutional one that serves as a mechanism for the erosion of the centrality of the service as the true vehicle for the sustenance of good governance and policy initiation, formulation, implementation and evaluation within the Nigerian state. In other words, the professionalism of the Public Administrators (Civil Servants) we have in mind here is quite different from that of the systemic or institutional professionalization that took place in Nigeria through military fiat in 1988 and, which clearly slaughtered the pillars of the service on the altar of political expediency and military arrogance. It is different in the sence that, unlike the military reform, which gave ascendancy to mediocrity in the Nigerian civil service, the professionalism in focus here is a tool for professional handling of the administrative affairs of the state as they affect good governance, efficient and effective service delivery to the citizenry.

This distinction finds a deep-seated solace in the fact that the so-called 1988 professionalization of the civil service only professionalized the institution to the detriment of the careerists as it led to the premature sunset of its first beneficiaries - [the Directors-General] - at the prime of their careers. This claim is supported by the fact that the military's professionalization of the civil service which had its roots in the military arrogance and its attendant bankruptcy of knowledge as to what constitutes the cornerstones of public administration or the civil service gave undue credence to office and/or nomenclature to the detriment of the careerists or occupants of such offices or institutions. It destroyed the foundation of the credibility of the service and, in the process opened it to ridicule through destructive political patronage which preferred mediocrity to meritocracy. The so-called military reform of the civil service substituted meritocracy with mediocrity and, in the process removed the values which at that time served as the magnetizing factors pulling capable, well educated, prepared, knowledgeable and competent materials to the service. Due to its preference for mediocrity and incompetence, it completely destroyed the administrative cadre which, even though, difficult to join by all and sundry, - thanks to the standardized competitive entrance examination conducted by ASCON, Topo, Badagry, Nigeria - remains the dreams of a preponderant majority of people seeking positions in the civil service.

It was a reform/professionalization agenda that crippled the civil service. It imported and/or transported dubious nomenclature of "Director-General" to the civil service. The dubiousness of this disturbing nomenclature is clearly explainable in what subsequently followed the political interference. Through it the civil service became the preserves of all comers and rejects - (with or without the necessary competence).

The interference in the guise of the so-called reform can be traced to its predecessor that took place in 1975 during which the Civil Servants were severely humiliated. It was a period political power was used through military fiat to deflate the ascendancy of the Public Administrators as a potent social force whose perceptions, interests and actions were determinant in shaping policies and strategies of government. The 1975 civil service purge which indisputably laid the chassis for the 1988 Babangida's reform of the same institution clearly gave credence to the detestation which the military had for the Public Administrators at that point in time. This political interference actually led to the unfortunate situation through which Officers who were not in the mainstream - Administrative Cadre - of the civil service were smuggled into the administrative arm of the service. As a matter of fact, such incompetent materials or rejects continuously gained entry into the administrative cadre of the service to the extent that they later found themselves at the apex of the service at certain points in time. As a matter of fact, a critical example that readily comes to mind here was the appointment of Officers in the Local Government Service as Permanent Secretaries against the existing "position-classification" requirements and the enabling Civil Service Regulations. In fact, through such interference some of such Officers eventually became Head of Service to the detriment of real Professionals who traditionally belonged to the Administrative cadre and, who actually went through the requisite competitive examinations prior to their recruitment into the civil service.

Prior to 1988 military's tinkering with the Nigerian civil service, the Administrative Cadre of the civil service was the dream of every civil servant including those already in the service - in different career lines - and those seeking to join it. This class of civil servants enjoyed benefits of good and prioritized postings to critical sections, offices and; sectors of the service. The level of their career advancement and rapidity of promotions 
was indeed, telegraphic and enviable. To a significant extent, at that time so many people in other career lines usually strived to cross-over to the administrative cadre and, were even very much willing to go through make-up competitive examinations which, probably they could not pass initially prior to joining different cadres of the service.

Without any doubt the so-called 1988 reform or professionalization of the civil service marked the beginning of the end of "Permanent Secretaryship" in the civil service before its belated reincarnation with the abolition of the same reform by the Abacha military oligarchy in 1995. The reform was the beginning of the practice whereby nothing was again permanent about permanent secretaryship in the civil service in Nigeria. Even now that a semblance of sanity seems to be coming back to the service in terms of competitive examinations for promotions and appointments of Permanent Secretaries or Head of Service, the fact that such positions are in most cases no longer tenure tracked but, instead tied to specific terms of office of two or more years and, the dependency of renewability of such appointments on political exigencies - which are always open to political manipulations makes it worrisome and absolutely disturbing.

With career professionalism and its propensity for willing collaborative relationship vis-à-vis the governance and policy processes, such policy madness - explainable in the dubiousness of the 1988 civil service reform - and its accompanying destruction of the public administrators' esprit de corps will diminish if not totally abated. Through it the pride of the civil service dismantled by the military reform of 1988 would be reincarnated if the reintroduction of promotion through competitive examination which started with the President Goodluck Jonathan Administration's promotion of the Federal civil servants including the Head of Service which has been adopted by some States of the Federation particularly Ekiti State, is allowed to continue.

There is no gainsaying the fact that Nigeria's public Administration needs transformation into one that will be most efficient, competent, self-confident, knowledgeable and Professional in the real sense of it to earn the the confidence and respect of the political class in that "career civil servants who are self-confident, highly competent, knowledgeable, dedicated and results-oriented professionals normally enjoy the respect of the political class regardless of the regime type" (Adamolekun, 2012). They have to be professional in that they possess the "instruments of Public Administration" which are "the main agents of change that preconceives, designs, implements and co-ordinates the process of change in the society. More importantly they are involved in "social engineering" that deals with "the action part of government, the means by which the purposes and goals of government are achieved. As a matter of fact, the complexities of administration and governance in contemporary time, have created "contours of modern management and a spectre of problems quite beyond the capacity of non-professional public servants. Nigeria's public service to be relevant for today and survive for the future must first of all become totally professional and knowledgeable about the problems associated with corruption. They must be particularly abreast of "new institutionalism" "network theory" and "governance theory" as mechanisms specifically designed to solve, ameliorate or "at least address the issues associated with the complexities of today's administrative world. In other words, they must be knowledgeable about the current trends and the position of Public Administration in the $21^{\text {st }}$ Century (Schiavo-Campo and Sundaram, 2001) particularly within the context of globalization and its "impact on most dimensions of government administration in most countries and constraints on the ability of national governments and their bureaucracies to act independently without collaboration.

The future of the public service in Nigeria, even though, specifically and concretely dependent to a significant extent, on compliance with the dictates and complexities of the technologically based villagized world and its thesis, can actually be guaranteed by the collaboration and adherence of the practitioners to the ethical obligations and codes of conducts - loyalty, accountability, courtesy and respect, discipline and integrity, honesty and impartiality and, confidentiality - which are the indispensable pillars of the public service (Shellukindo and Baguma op cit: 26).

It is through respect for these obligations, that the degeneration of public service ethics which has been variously contextualized in terms of the ascendancy of corruption and proclivities for Kleptocracy by public officials in the course of performing their official duties can be reversed for the sustainability of the Nation's public service for today and the future. The sustainability is equally dependent on good leadership and; the provision of enabling environment by the State for the realization of what has been termed practical agenda for promoting ethics and accountability in contemporary African public service (Rasheed, 1993:289).

\subsection{Good Leadership as Enhancer of Effective Collaboration}

Leadership is "the ability to get men do what they don't want to do and like it" (Cohen et al, 1984). It is "the process of social influence in which one person can enlist the aid and support of others in the accomplishment of 
a common task. It is ultimately about creating a way for people to contribute to making something extraordinary happen". Leadership is "the process of using power to obtain interpersonal influence" (Schermerhon Jr., Hunt and Osborn, 1985). This is more so in that:

\section{Leaders today work in socially intricate organizations where they need the assistance not only of subordinates but also of peers, superiors, and external parties to accomplish their goals. Accomplishing goals that positively impact the organization requires effective leadership linked to strong power bases and workable influence strategies. Building a strong power base and developing effective influence strategies to produce power dynamic is an important leadership challenge. (Michelson, nd).}

The need for effective leadership is compelled by the fact that "everything rises and falls on leadership" and, the "success or failure of every human endeavour depends solely on the kind of leadership available for such endeavours" (YHDC, Leadership training, 2009). Thus, "a leader in an organization or political setting is an embodiment of a force that directs the entire organization towards the realization of the organizational goals" (Denga, 1986; Esere nd). Concretely put, leadership connotes "ability to inspire, direct, motivate and encourage others positively to targeted end. It is the ability to lead others". It "represents authority and the pinnacle of the organization. It is the form that authority assumes when it enters into process" (Olusoji, 2002; Mooney and Rieley, 1931 and 1947).

Nigeria needs a change leadership for it to get out of her political woes - corruption, culture of settlement, administrative lawlessness, greed and avarice amongst others - foisted on her and her people by a preponderant majority who have through one way or the other always found their ways into the nation's high level administrative structures or institutions both at the national and state levels.

A change leader is a key to large-scale, sustainable reform. It is a leader that is committed to sustained and sustainable innovation in his quest for organizational effectiveness. It is a focused leader who is committed to the development of knowledge and skill within his organization particularly in terms of programme coherence and technical resources (Newmann et. al, 2000). He is one who “catalyzes commitment to a compelling vision and higher performance" and who seeks deep and lasting reforms through the establishment of conditions aimed at the attainment of "enduring greatness" (Collins, 2001, Akindele and Adeyemi, 2012).

\section{Why the Super-bureaucracies and their Bureaucrats Must Collaborate Through Inter and Intra Agency/Institutional Relationship in Ekiti State, Nigeria}

The choice and use of the adjective "Tripodic" in describing the three critical super-bureaucracies of the state and their functionaries is deliberate because they are constantly adjustable through re-organization, modification, removal, redeployment using the instrumentalities of office executive powers. This is clearly put into perspective by their chequered history:

....the history of the Civil Service Commission has all along been rather steady, those of the offices Secretary to Government and Head of Service have been rather zig-zag. The first well known Secretaries to government in Nigeria in the colonial era were Donald Cameron who was styled "Chief Secretary" at the "Central Secretariat" in Lagos; Major Moorhouse as Secretary Southern Provinces; and Mr. Mathew as Secretary Northern Provinces. They were appointed by Sir. Frederick Lugard, who was Governor of Nigeria. At Independence in 1960, the title changed to Secretary to the Prime Minister in person of S. O. Wey. After the takeover of government by the military in 1966, the title changed to Secretary to the Federal Military Government at the centre and the office was occupied by M. A. Ejueyichie and later A. A. Atta. Somehow by the time of C. O. Lawson, the title of the office has changed to Secretary to the Federal Military Government and Head of Service. Lawson was succeeded by A. A. Ayida, A. L. Groma, S. A. Musa, G. A. E. Longe and Adamu Fikka. Adamu Fikka was later divested of the aspect of Secretary to Government and made to retain only the aspect of Head of Service......there was a lot of tinkering with the two offices. While between 1966 and 1979 they were merged as Secretaryto Government and Head of Service, the 1979 constitution separated it into two offices of S. S. $G$ and H. O. S. But by 1984, the Buhari military regime merged them again into one office SMG and H.S. However, by 1988 General Babangida atrociously abolished the office of the Head of Service through a bogus Civil Service Reform, only to be restored soon after by 
General Abacha. Such was the chequered history of the office of the S. S. G and H. O.S in

Nigeria(Omiyale, 2012).

These super-bureaucratic institutions of governance are very critical to the state vis-à-vis the governance process. The extent to which these tripodic institutions can sustain themselves amidst the constant political onslaught of the Executive will be determined by their ability and willingness to collaborate in the performance of their respective functions.

\section{Functions of the Tripodic Bureaucracies}

The functions of the tripodic bureaucracies - with a moderate or contestable exception of the CSC - are to some extent determined by political considerations. Some of such delegated functions as articulated by Omiyale (2012) are synoptically highlighted in this section.

6.1 Functions of the Office of the Secretary to the State Government - SSG

The SSG is responsible for overseeing the affairs of the under listed critical areas or segments of the state:

- Cabinet Secretariat.

- Meetings of the Executive Council.

- Matters relating to the Legislature.

- Constitutional or political matters such as Tribunals and Commissions of Inquiry.

- State Security and public safety.

- Directing the Ministries, Departments and Agencies (MDAs) regarding government policies and decisions.

- Maintaining contacts with Political Executives in the various departments.

- Protocol Affairs.

- Intergovernmental Relations.

- National Honours and Related Matters and, any other duties that may be assigned by the ultimate political leadership.

6.2 Functions of the Office of the Head of Service - HOS

The functions of the Head of Service amongst others include responsibility over the affairs of the following administrative duties:

- Implementations of government decisions by the Ministeries, Departments and Agencies (MDAs).

- Coordination of all service matters generally.

- Handling matters of recruitment, appointments, promotion and discipline of career officers in conjunction with Civil Service Commission.

- Protecting or guarding the integrity of service rules and regulations, ethics and norms.

- Training and staff development.

- Grading and Pay, and Establishment matters generally such as personnel records.

- Deployment of staff to different areas of the service as may be called for from time to time.

- Pensions and service welfare matters.

- Looking after labour matters such as dealing with labour negotiating council or committees.

- Allocation of vehicle and other logistics to enhance the performance of MDAs and their staff and, any other duties that may be assigned by the political leadership of the state.

6.3 Functions of the Civil Service Commission - CSC

The functions of the Civil Service Commission which can be contended to have remained clear and steady over the years within the administrative landscape and terrains of the Nigerian state without the constant alterations and political determinism which have characterized those of the SSG and HOS include amongst others the "recruitment and appointment of staff and; promotion and discipline of staff".

It is important to note the fact that, the seeming hierarchical nature of these three critical super-bureaucracies notwithstanding, the strength of the office of the SSG through political leverage over the offices of the HOS and CSC constitutes the latter's' advantage over the former. The HOS enjoys a semblance of permanence in office over the SSG to some extent in that the latter is more political than administrative. While the tenure of the SSG is actually tied to that of a given political Regime and, may hardly in some cases continue beyond the first term in case the Regime gets a second term in office, the other institutional super-bureaucracies - HOS and CSC - are not always victims of this political exigency due to certain statutory stipulations which to some extent insulate them against such expedient political considerations. However, only the CSC to some extent enjoys a fixed term of office which may not always be easily slaughtered on the altar of political exigency even though their 
appointments are made through political consideration. But then, there have been cases where the Executives tampered with such appointments prior to the completion of the stipulated tenure and such actions led to litigations.

While emphasizing the need for collaboration among these institutions, we are not unmindful of the differences in the expectations tied to their functional purviews and, that such expectations are determined by the nature of the emergence of the tripodic bureaucracies. This is exemplified by the fact that the Office of the SSG is both political and administrative and does not fully fall within the parameters of the traditional values/criteria of public administration as it is both heard and seen unlike the Office of the HOS and its functionaries who are only heard and not seen in line with the orthodoxy of public administration not minding the currency given to the political character of public administration. While the Office of the HOS and its practitioners are only seen but not heard, the CSC is the gatekeeper which determines who enters or does not enter the public service (civil service). It has the same pedigree in terms of political appointment into office like the SSG. Even though the determinism involved in the emergence of the HOS is to some extent political its political consideration is guided by civil service rules and regulations which are not really applicable to the other two. However, it should be stated that the political consideration involved in the emergence of the HOS seemed to have been diminished by the reintroduction of competitive examination as one of the critical requirements for the appointment of Permanent Secretaries and the HOS during the fourth phase of Nigeria's fourth Republic.

Given the variations in the emergence; conditions of services and; expectations from these tripodic super-bureaucracies, the only way through which they can constantly survive the premature political annihilation of the Executive is for them to collaborate in pursuit of efficient, effective and responsive service delivery given the fact that:

...the three offices we are dealing with are in coordinate partnership and not in subordinate
partnership. Maintenance of smooth relationship is easier to handle in subordinate
partnership where one authority necessarily has to defer to a higher authority in the chain of
command. But where authorities are at par as in coordinate partnership, greater care is ever
needed not to rock the boat unnecessarily or rub the other partner on the wrong side.
Situations had occurred where the office of the Head of Service clashed with the Civil Service
Commission in unnecessary tussle. This should never have been so if all parties were
sufficiently conscious of the ethics of their relationship. They are cooperating and not
competing offices (Ibid.).

\section{The Contemporary Trend in Ekiti State}

Competitive examinations as one of the critical requirements for appointments and promotions of the staff in the Civil Service were actually evoked in Ekiti State in 2010 in respect of the appointment of the state's HOS and Permanent Secretaries. The requirement was extended to the education sector in the course of the state's quest for more robust and sound education of its people. Thus, Ekiti State offers a good example in the revamping of the civil service as a critical engine of the state in line with the orthodoxy of rational bureaucracy and its imperatives of hierarchy of authority, impersonality, technical competence, specialization, discipline and, meritocracy which were swept away by inglorious previous reforms.

With its contemporary focus which has a perfect symmetry with the currents of public administration in the $21^{\text {st }}$ century, the political and extra-systemic considerations which have fatally crippled the public service have been completely dismantled in the state. As a matter of fact, in its quest for efficient, effective, results-oriented, professional, dedicated, knowledgeable, competent, accountable and financially prudent civil service and servants, the Ekiti State government, in 2010, introduced measures for achieving "strong implementation capacity" of the state's civil service "through the Civil Service Transformation Strategy (CSTS)" (Adamolekun, 2012). The rationality of the state's philosophy in this regard was predicated on the belief that its 8-Point Agenda - [of participatory and accountable "governance, infrastructural development, modernizing agriculture, education and human capital development, health care services, industrial development, tourism and, gender equality and empowerment"] - can only be achieved by jettisoning a "civil service characterized by intense politicisation, limited efficiency and effectiveness and low morale"(Adamolekun, 2012; see also the Road Map to Ekiti Recovery: 8-Point Agenda). While the requirements and task associated with this new thinking remain largely daunting, "it is not an insurmountable challenge" from the perspective of the political leadership of the state (See Fayemi, 2010).

The main goal of the CSTS in Ekiti State is "to transform the civil service through critical institutional changes, re-engineering of management systems and processes, and restoring merit, professionalism, and competence, 
into a value-based and results-oriented institution within eight to ten years" (Adamolekun, 2012) hence, it is predicated on the key result areas of Effective governance of the civil service; Organizational efficiency and effectiveness; Professional and results-oriented civil servants; Ethical and accountable workforce with a changed work culture; Improved competence of civil servants; and Improved public financial management (CSTS, Ekiti State *-Point Agenda, 2010; also cited in Adamolekun, 2012).

The evocation of the competitive examination as one of the requirements for recruitment and promotions in Ekiti State is in perfect conformity with the traditionalism of the civil service which was jettisoned in Nigeria through the policy blindness of the military reformers in exchange for a civil service characterized by mediocrity and limited efficiency and effectiveness, low morale and productivity. This traditionalism which takes civil servants as "administrators paid for implementing the policies of national governments" (McLean and McMillan, 2003) was predicated on "the implementation of the Northcote-Trevelyan reforms in the second half of the nineteenth century" which signalled the origin of the civil service as a modern bureaucracy. These reforms at that time and beyond ensured that:

- Entrance to the civil service was by competitive examination, both for the administrative (highest) and executive (intermediate) classes. Promotion was also on merit.

- The civil service became a life career and hence a profession for the educated to enter into

- The tasks of civil servants were divided into intellectual and routine. This meant that departments developed as hierarchic: those drawn from the administrative class filled senior policy advice positions; those from the executive class filled positions defined by their superiors; and those on clerical grades-the least intellectual-carried out routine work.

- The civil service as a permanent institution of government developed an ethos of political neutrality, willing and able to advise and serve elected government of any party programme (Ibid.)

The foregoing closely mirrors Weber's ideal-type bureaucracy which has definitely become the blue print for the analytical consideration of the organizational landscapes both in the public and private sectors of all polities of the world (See Akindele, 2010).

The need for the continuous applicative sustenance of these imperatives of Weberian bureaucracy in ways conducive to the pursuit of good governance and its attendant provision of efficient, effective and responsive services to the citizenry makes the type of collaboration in perspective here indispensable within the landscape of any state's civil service.

\section{The Benefits of Collaboration}

Through collaboration the sate and the citizenry will immensely benefit because the super-Bureaucrats will be able to free the state from the clutches of some problems which can completely wreck her engine of development. This is particularly so because, in dealing with policy initiation, formulation and implementation, the super bureaucrats under reference will increasingly and jointly become more aware of the three major alternatives or grounds - [provision of a policy; best known alternative and; absence of a policy] - for policy evaluation and the applicative utility of the criteria - [efficiency, effectiveness, equity, adequacy, feasibility, ethics and technology] - against which public policy can be evaluated . By so doing, they will be equipped with the competence to constantly distinguish policy input (PI) from policy output (PO) within the framework of policy analysis and public policy hierarchy PPH and, the quadrupled categories - political policy, executive policy, administrative policy and technical policy - involved (Akindele, 2000). Through this sound knowledge they will be able to increasingly rescue the state from the deep waters of economic mismanagement and wastage and, in the process enhance national development.

Given the challenges associated with authoritative allocation of the scarce and critical societal values or, the determination of who gets what? when? where? how? and why? among the various competing groups or interests within the polity and, the "need to accelerate development" and, and achieve a wider distribution" of the gains of government (Meier, 1984), such a collaboration must be striven for. From such collaboration, avoidance of the abuses in the public and financial sector of the nation's economy and adoption of optimal strategy for effective management of the economy will automatically become part of the values of the public service thus, improving "the choice of policy instruments and methods of implementation".

These aside, the "gap between the needs and expectations of citizens and government employees for government services and benefits (Levine, 1980) further necessitates the need for inter and intra institutional collaboration in most polities of the world. Thus, with the collaboration, policy, objectives would be streamlined to enable government and its bureaucrats to recognize and make available needed legal and institutional framework for nationally beneficial goals. 
The benefits attributable to collaboration among the super-bureaucracies and their functionaries can be better harnessed if certain reorganization can take place within the state's civil service. In fact, it is our contention that the attractiveness of collaboration as an ingredient of good governance, efficient and effective service delivery within our democracy notwithstanding, its workability; sustainability and; productivity in terms of responsive policy inputs and outputs; institutional viability and stability is dependent on certain tradeoffs and compromises. These on their own, are contingent on the ability of the state to reorganize its various agencies and institutions vis-à-vis the expected fine-tuning and reduction of apparent areas of economic and administrative wastages and; plundering of critical resources associated with the avoidable crippling overlaps among several of the State's Parastatals.

Specifically it is recommended that the civil service should be transformed such that overlapping functions are reduced to the barest minimum to allow for genuine collaboration. Through this reorganization the financial management system will be improved with its attendant positive consequences for developed and improved fiscal management. Through it, revenue generation agencies will equally be strengthened through transparency; healthy budgetary process; accountability; prudent management of resources; reduction of fiscal stress and fiscal crises; integrity in bureaucratic conducts and its accompanying reduction of bureau-pathologies; and change leadership. This reorganization will not be problematic if the willingness required for it is not idiosyncratically ostracized by the relevant actors of the state. More importantly, the blue print for such reorganization - [which, in the case of Ekiti State, is explainable within the matrix of the 8-Point Agenda of the government that came into office in October, 2010] - should be the brainchild of all and sundry including the super-bureaucracies and their functionaries serving as the technocrats.

Without any doubt, the ball is in the courts of the super-bureaucrats within the super-bureaucracies in Ekiti State. Once these levels of the administrative machinery of the state inculcate the values of dedication to duties; results-orientated professionalism and, collaborative relationship irrespective of the trade-offs and costly compromises they require, the civil service in the state and, indeed, in Nigeria will regain its loss glory and enviable position in the scheme of things vis-à-vis the administrative landscape and its constantly slippery topographic terrains. Through such dedicated professionalism, self-confidence, knowledgeable and results-oriented dispositions, our civil service and servants of today - [as institutions and people saddled with "heavy and multifarious burdens"] - can be equally described, appreciated and praised the way Chief Obafemi Awolowo (1960. 293; also cited in Adamolekun, 2012) appreciated and glowingly described the Western Region Civil Service and Servants of the 1950s when he stated thus:

Our Civil Service is exceedingly efficient, absolutely incorruptible in its upper stratum, and utterly devoted and unstinting in the discharge of its many onerous duties. For our civil servants, government workers and labourers to bear, uncomplainingly and without breaking down, the heavy and multifarious burdens with which we have in the interest of the public saddled them, is an epic of loyalty and devotion, of physical and mental endurance, and of a sense of mission, on their par. From the bottom of my heart I salute all of them.

This, in itself, will propel the civil service and its practitioners as critical actors and players of the state to prominence and relevance in line with the thesis of today's global village and its "mondialization" of the governance process in our democracies.

\section{Conclusions}

The issue of collaboration with reference to good governance, efficient and effective service delivery has been examined in this paper. In the process, the concepts of institutionalism and public service were elucidated in line with core theoretical constructs.

The discourse of collaboration among the administrative institutions of government zeroed in on the super-bureaucracies and their functionaries. The need for such collaboration; its benefits; what the Public Administrators should do to enhance it, as well as the relevance of technocracy and other bureaucratic principles to the process were analyzed.

The reincarnation of the orthodoxy of the civil service and what it actually entails as exemplified by the wider currency lately given to competitive examination as the major prerequisite for recruitment and promotions in the civil service in Nigeria and, particularly in Ekiti State has been identified as a healthy development.

\section{References}

(1979). Webster's New Universal Unabridged Dictionary. London: Dorset and Baber.

(1993). Sharing Power: Public Governance and Private Markets. Washington, D.C.: The Brookings Institution. 
(2010). The Nerves Of Organization: A Genealogical Discourse of Organizational Theory and its Threads. Saarbrucken: LAP Lambert Academic Publishing GmbH \& Co. KG.

Adamolekun, L. (1983). Public Administration: Nigerian and Comparative Perspective. London: Longman.

Adeyemi, O. O. (2011). Corruption and the Nigerian State: A Critical Discourse. Saarbrucken: LAP Lambert Academic Publishing GmbH \& Co. KG.

Adeyemi, O. O. (2012). Leadership: A New Synthesis. International Journal of Physical and Social Sciences, $2(1)$.

AIT. (2011). Focus Nigeria Programme.

AIT. (2012). Focus NigeriaProgramme: National Security: Dissecting The Boko Haram.

Akindele, S. T., Obiyan, A. S., \& Owoeye, J. (2000). The Subject matter of Political Science (2nd ed.). Ibadan: College Press and Publishers Ltd.

Awolowo, O. (1960). Awo: the Autobiography of Chief Obafemi Awolowo. Cambridge: Cambridge University Press.

Cohen, A. R. (1984). Effective Behaviour in Organizations. Homewood: Irwin.

Collins, J. (2001). Good to great: Why some companies make the leap....and other don't. New York: Harper-Collins.

Denga, D. I. (1986). An Introduction to Foundation of Education. Calabar: Advanced Publishers \& Printing.

Ekiti State Government. (2010). Road Map to Ekiti Recovery: 8-Point Agenda.

Ekiti State Officials' Retreat. (2012). Institutional collaboration as essential ingredient for good governance, efficient and effective service delivery in a democracy: A critical focus on the tripodic super-bureaucracies of the state and their practitioners. Iloko Ijesa, Osun State, Nigeria.

Erero, J. (2000). Accountability in the Management of Public Institutions in Nigeria: A Local Government Perspective. In Mukoro. A. (Ed.), Institutional Administration: A Contemporary Local Government Perspective for Nigeria (chapter 5). Lagos: Malthouse Press Limited.

Esere, M. O. Leadership Styles of Husbands in Homes: Implications for Family Stability. The Nigerian Journal.

Fayemi, K. (2010). The Inaugural Speech of Ekiti State Governor.

Frederickson, H. G. (1999). The Repositioning of American Public Administration. Political Science and Politics.

Fullerton, R. (2002). Political Leaders Must be held Accountable for Corruption. Cross roads, 6(4), 5-6.

Gould, J. (1972). A Dictionary of Social Sciences. New York: UNESCO Publication.

Gould, J., \& Kolb, W. L. (1964). Dictionary of Social Sciences.

Ibodje, S. W. E. (2000). Elements of Public Administration. Nigeria: Eregha Publishers.

Kaunda, K. D. (2003). Democratization; Development; and the challenges for Africa. Africa Notes (pp. 1-5). New York: Cornell University.

Kettl, D. F. (1988). Government by Proxy: Managing Federal Programs. Washington, DC: CQ Press.

Kukah, H. M. (1995). Political stability, the leadership question and the inevitability of instability. In J. L. Isa (Ed.), Not in our character: Proceedings of the National Conference on the appraisal of the social and moral image of the Nigerian society. Kaduna: Kaduna State Government.

Levine, C. (1980). Managing Fiscal Stress: The crisis in the public sector. New Jersey: Chattam House Publishers.

Lynn, L. E. (1996). Public Management as Art, Science and Profession. Chattam, NJ: Chatham House.

Malena, C., \& McNeil, M. (2010). Social Accountability in Africa: An Introduction. In M. McNeil, \& C. Malena (Eds.), Demanding Good Governance: Lessons from Social Accountability Initiatives in Africa (pp. 1-28). Washington: The International Bank for Reconstruction and Development/The World Bank.

March, J. G., \& Olsen, J. P. (1984). The New Institutionalism: Organizational Factors in Political Life. American Political Science Review, 78, 734-749. http://dx.doi.org/10.2307/1961840

McLean, I., \& McMillan, A. (2003). Oxford Concise Dictionary of Politics. Oxford: Oxford University Press.

McNeil, M., \& Malena, C. (2010). Demanding Good Governance: Lessons from Social Accountability Initiatives in Africa. Washington: The International Bank for Reconstruction and Development/The World Bank.

Meier, G. M. (1984). Leading issues in Economic Development (4th ed.). New York/Oxford: Oxford University Press.

Michelson, B. J. Leadership and power base development: Using Power Effectiveness to manage Diversity and Job-related Interdependence in Complex Organizations.

Mooney, J. D. (1947). The Scalar Principles. In J. D. Mooney, \& A. C. Rieley (Eds.), The Principles of Organization. New York: Harper and Brothers. 
Newmann, F., King, B., \& Younge, P. (2000). Professional Development that Addresses School Capacity. New Orleans, LA.

Olusoji, A. (2002). The Making of a Leader: Exploring the Skills of Leadership. Lagos: Leadership Publishing House.

Omiyale, A. J. (2012). The Roles and Interrelationships of the Offices of the Secretary to the State Government, Head of Service and the Civil Service Commission in a Democratic Dispensation. Leadership and Functionaries of the Offices of the SSG, HOS and CSC at the Royal Park Hotel, Iloko-Ijesa.

Powell, W. W., \& DiMaggio, P. J. (1991). The New Institutionalism and Organizational Analysis. Chicago: University of Chicago Press.

Rainey, H., \& Steinbauer, P. (1999). Galloping Elephants: Developing Elements of a Theory of Effective Government Organizations. Journal of Public Administration Research and Theory, 9, 1-32. http://dx.doi.org/10.1093/oxfordjournals.jpart.a024401

Rasheed, S. (1993). Conclusion: Towards an Agenda for Action in Enhancing Ethics and Accountability in African public Services. In S. Rasheed, \& D. Olowu (Eds.), Ethics and Accountability in African Public Services (pp. 284-304). Addis-Ababa: United Nations Economics Commission for Africa.

Rieley, A. C. (1931). Onward Industry. New York: Harper and Brothers

Rieley, A. C. (1947). The Principles of Organization. New York: Harper and Row Publishers.

Salomon, L. M. (1989). Beyond Privatization: The tasks of Government Action. Washington, DC: Urban Institute Press.

Schattschneider, E. E. (1960). The Semi-Sovereign People. New York.

Schermerhorn, J. R., Hunt, J. G., \& Osborn, R. N. (1985). Managing Organizational Behaviour. New York: John Wiley and Sons.

Schiavo, C., \& Sundaram, S. (2001). Improving Public Administration in a Competitive World. In Asian Development Bank (pp. 1-23).

Shellukindo, W. N., \& Baguma, R. (1993). Ethical Standards and Behaviours in African Public Services. In S. Rasheed, \& D. Olowu (Eds.), Ethics and Accountability in African Public Services. Addis Ababa: United Nations Economics Commission for Africa.

Wilson, J. Q. (1989). Bureaucracy: What Government Agencies Do and Why They Do It. New York: Basic Books.

Wolfgang, W. (1991). Responding to Citizens' Needs: From Bureaucratic Accountability to Individual coproduction in public sectors. In F. X. Kaufman (Ed.), The Public Sector: Challenge for Coordination and Learning (chapter 4). Berlin and New York: Walter De Gruyter.

Youth Heritage Development Centre (YHDC). (2009). Styles of Leadership. Leadership Training. 